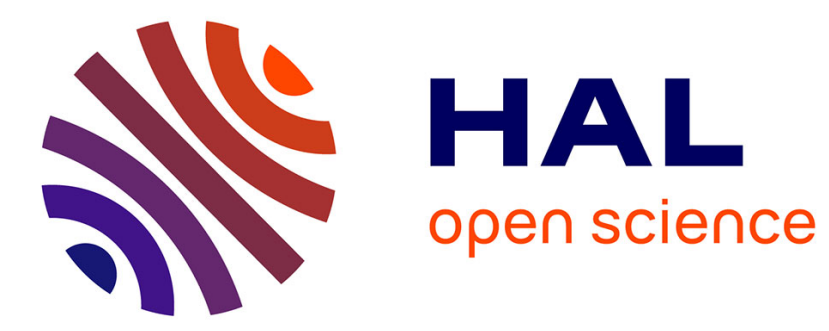

\title{
Cycloisomerization of Dienynes by a Planar-chiral Gold(I) Complex
}

Z. Wu, K. Isaac, P. Retailleau, Jean-François Betzer, J.-F. Betzer, A. Voituriez, A. Marinetti

\section{> To cite this version:}

Z. Wu, K. Isaac, P. Retailleau, Jean-François Betzer, J.-F. Betzer, et al.. Cycloisomerization of Dienynes by a Planar-chiral Gold(I) Complex. SYNFACTS, 2016, 12 (04), pp.0393-0393. 10.1055/s0035-1561823 . hal-02152298

\section{HAL Id: hal-02152298 \\ https://hal.science/hal-02152298}

Submitted on 22 Oct 2019

HAL is a multi-disciplinary open access archive for the deposit and dissemination of scientific research documents, whether they are published or not. The documents may come from teaching and research institutions in France or abroad, or from public or private research centers.
L'archive ouverte pluridisciplinaire HAL, est destinée au dépôt et à la diffusion de documents scientifiques de niveau recherche, publiés ou non, émanant des établissements d'enseignement et de recherche français ou étrangers, des laboratoires publics ou privés. 


\section{Cycloisomerization of Dienynes by a Planar- chiral Gold(I) Complex}

Metal-Catalyzed Asymmetric Synthesis and Stereoselective Reactions

\section{Key words}

gold catalysis

paracyclophanes

cycloisomerization

dienynes

Selected examples:<smiles>C=CC1CC(C)(c2ccccc2)C=CN1[13CH3]</smiles>

$92 \%$ yield, $90 \%$ ee, $\mathrm{dr}=95: 5$<smiles>C=CC1C[C@](C)(c2cc(C)cc(C)c2)C=CN1[13CH3]</smiles>

$95 \%$ yield, $88 \%$ ee, $\mathrm{dr}>95: 5$<smiles>C=CC1C[C@](C)(c2ccc(OC)cc2)C=CN1[13CH3]</smiles>

$93 \%$ yield, $83 \%$ ee, $\mathrm{dr}=95: 5$<smiles>C=CC1C[C@](C)(c2ccc(Cl)c(Cl)c2)C=CN1[13CH3]</smiles>

$71 \%$ yield, $84 \%$ ee, $d r=95: 5$

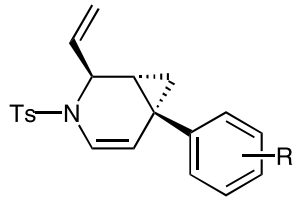

9 examples up to $96 \%$ yield up to $95 \%$ ee dr up to $>95: 5$

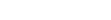

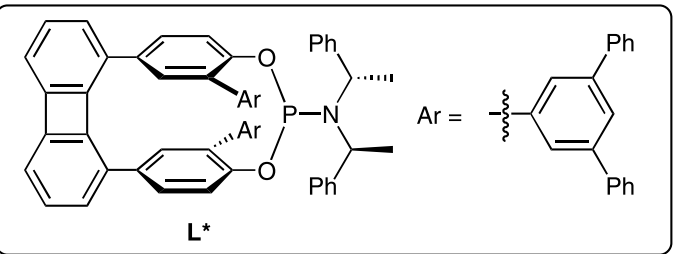<smiles>C=CC1C[C@](C)(c2ccc([N+](=O)[O-])cc2)C=CN1[13CH3]</smiles>
$33 \%$ yield, $67 \%$ ee, $d r=95: 5$<smiles>[3H]N1C=C[C@@](C)(C2(OC)CC(C=C)C=CC=C2OC)CC1C</smiles>

$94 \%$ yield, $95 \%$ ee, dr $>95: 5$
Significance: The gold $(I)$ catalyst shows a strong affinity for unsaturated (triple) bonds, and subsequent cycloisomerization reactions with various nucleophiles (carbon, heteroatom) are a powerful tool for the construction of cyclic molecules. However, asymmetric variants of these reactions are challenging because of the nature of a linear coordination of the gold complex. The authors describe new chiral phosphoramidite ligands based on a planar-chiral paracyclophane scaffold. The cycloisomerization reaction of dienyne substrates afforded the bicyclic products in high yield with good to excellent diastereo- and enantioselectivity.
Comment: By using the reported phosphoramidite ligand, dienynes having enantiotopic vinyl groups were successfully transformed into the products bearing three contiguous stereocenters (platinum-catalyzed reaction of this type of substrates gave moderate yield, see: Adv. Synth. Catal. 2011, 353, 1109). The unactivated substrates bearing an electron-deficient aryl group were also tolerated and gave the desired product in moderate yield with excellent diastereoselectivity and good enantioselectivity. 